\title{
Minimum Map of Social Institutional Network: a multidimensional strategy for research in Nursing*
}

\author{
Mapa mínimo da Rede Social Institucional: uma estratégia \\ multidimensional de investigação na Enfermagem \\ Mapa mínimo de la Red Social Institucional: una estrategia \\ multidimensional para la investigación en Enfermería
}

Diene Monique Carlos ${ }^{1}$, Elisabete Matallo Marchesini de Pádua², Ana Márcia Spanó Nakano¹, Maria das Graças Carvalho Ferriani

\footnotetext{
* Paper extracted from the thesis "O cuidado em rede a famílias envolvidas na violência contra crianças e adolescentes: o olhar da Atenção Básica à Saúde ", presented to Escola de Enfermagem de Ribeirão Preto, Universidade de São Paulo, SP, Brazil.

${ }^{1}$ Escola de Enfermagem de Ribeirão Preto da Universidade de São Paulo, Ribeirão Preto, São Paulo, SP, Brazil.

${ }^{2}$ Pontifícia Universidade Católica de Campinas, Campinas, São Paulo, SP, Brazil.
}

\begin{abstract}
Objective: To analyze the use of methodological strategies in qualitative research Minimum Maps of Social Institutional Network, as proposed to understand the phenomena in the multidimensional perspective. Method: methodological theoretical essay in which we aimed to reflect on the use of innovative methodological strategies in nursing research, supported in Complex Paradigm fundamentals. Results: The minimum map of Social Institutional External Network aims to identify institutional linkages and gaps for the intervention work of the surveyed institutions. The use of these maps provided important advances in know-how qualitative research in Health and Nursing. Conclusion: In this perspective, the use of minimum Social Intitutional Network maps can be stimulated and enhanced to meet the current demands of the contemporary world, particularly for its flexibility in adapting to various research subjects; breadth and depth of discussion; and possibilities with health services.
\end{abstract}

DESCRIPTORS

Qualitative Research; Nursing; Community Network. 


\section{INTRODUCTION}

For some years, there has been a paradigmatic transition in health and some landmarks were important for such a change. The Alma Ata Conference in 1986 that references the Primary Health Care (PHC), and the Charter of Ottawa in 1986 that legitimizes the promotion of health, constitute two of these milestones. PHC is now seen as essential attention and an international measure to obtain better quality of life $\mathrm{e}^{(1)}$. Health promotion starts from a broad conception of the health-disease process and its determinants. It presents the articulation of technical and popular knowledge and the mobilization of institutional and community resources as essential elements to face and solve health problems ${ }^{(2)}$.

In this scenario, the $8^{\text {th }}$ National Health Conference was held in Brazil in 1986, referencing the movement of Health Reform that had started in the previous decade and recognizing health as a universal right and duty of the State. This marked the beginning of construction of the Unified Health System (SUS - Sistema Único de Saúde). In this sense and seeking to overcome the logic opposition of health-disease, is proposed an expanded concept of health that is closer to the concept of health promotion ${ }^{(3)}$.

Indeed, from the law number 8080/1990, which regulates the SUS and the National Humanization Policy of SUS Care and Management, we emphasize the new concept of health: 'Health is a social production, the result of complex causal relationships that involve biological, subjective, social, economic, environmental and cultural elements that are processed and summarized in the concrete experience of each individual, of each particular group and society in general' $(4: 10)$.

Thus, the own concept of health indicated the need of developing coordinated actions from different sectors, namely multi and interdisciplinary actions, inter and multi-sectoral, signaling the passage from a 'reductionist model of health, focused on disease, to a complex view of health, multifactorial, territorialized, systemic and focused on the subject-environment relationship' ${ }^{\text {(5:51) }}$.

According to new guidelines from the Ministry of Health, the recommendation is the current integration of available resources to attend the population in a network of care, guided by primary health care and following the model of care line. The Care Line is a way to obtain 'full care' or 'comprehensive care'. This model offers assistance from primary care until the levels of higher technological density, providing also the interaction with other sectors ${ }^{(6)}$.

Nursing, as a professional nucleus in the health field, has human beings as its work object, and the care to human beings (individual or collective/singular or community) as its objective throughout the health-disease process and the factors that affect it. All these elements are considered together a complex object located in a challenging research field ${ }^{(7)}$. In the context of paradigmatic transition, researchers in nursing have been developing and exploring various investigative techniques supported by different theoretical frameworks, since new strategies are needed for understanding the reality ${ }^{(8,9)}$.
The focus on PHC, health promotion and the care in nursing are contemporary issues that need further discussions under a new prism. This look speaks to the complexity paradigm using one of its main authors, Edgar Morin, as reference. The proposal is a complex thinking to approach what is 'woven together', implying on considering the different and sometimes contradictory parts that are articulated in the composition of phenomenon and inserted in a context of dialogical perspective. For this objective, there must be a polyocular view of the phenomenon $^{(10)}$.

Within this sense, in the scope of qualitative research, the contextualization of the knowledge object becomes one of the key ideas of the complex thinking and relevant knowledge. The author states that 'knowledge can only be relevant if its object is placed in context and if possible, in the global system of which it is part, if it creates an incessant form that separates and reunites, analyzes and synthesizes, abstracts and reinserts in the concrete ${ }^{\text {(11:91) }}$.

Or explains that 'the knowledge of information or data isolatedly is insufficient. It is necessary to place the information and data in their context in order that they acquire meaning ${ }^{\text {(12:36) }}$.

This study is a methodological theoretical essay in which we sought to reflect about the use of innovative methodological strategies in nursing research that address the understanding of phenomena and realities in the polydisciplinary and polyscopic dimensions sustained in the foundations of the Complex Thought. Thus, this study aimed to analyze the use of methodological strategies in qualitative research - the Minimum Map of Institutional Social Network as a proposal to understand the phenomena in the multidimensional perspective.

The relevance of the proposal is in line with new governmental guidelines on health policies, focused on PHC and health promotion. The construction of new theoretical approaches and methodological strategies helps to meet the contemporary demands in the field of research and practice in health, nursing in particular, and indicate ways for more relevant and consistent care approaches in this area.

\section{METHOD}

For Morin, the method is very challenging and conclusive. It recreates a conception that transposes the group of knowledge and formal procedures linked to a principle of order, of superior scientific rigor and deductive logic for seeking complex explanations of the social reality ${ }^{(10)}$. The author also distinguishes theory from method, considering that the theory is not knowledge, but empowers knowledge when stating that '[...] theory is an engram, and the method needs strategy, initiative, invention and art to be established [...]. The method is the phenomenal, subjective, concrete, $\operatorname{praxis}^{{ }^{\prime(10: 335)}}$.

Thus, based on the consistency between theory and method, the theory comes to life only with the intervention of the subject, and the subject conceives strategies and techniques for this intervention. It allows the use of subjects' most special qualities, mobilizing their thinking activity and $\operatorname{art}^{(13)}$. 
Morin's understanding becomes clear with the following affirmation: 'one should remember here that the word method does not mean methodology at all. A priori, methodologies are guides that program researches, whereas the method derived from our course will be an aid to strategy (which will include certain programmed segments, i.e., methodologies, but will necessarily comprise discovery and innovation). Herein, the purpose of the method is to help individuals to think for themselves in order to meet the challenge of problem complexity ${ }^{\left({ }^{\prime}(4)\right.}$. This understanding is also highlighted on Ciência com Consciência (not published in English) ${ }^{(10: 337)}$, a classic work of the author, when discussing theory and method, stating that 'the method is the thinking activity of the subject'.

Moreover, the meaning of strategy contributes and expands in qualitative research, since, as stated by Morin, it allows ${ }^{(15: 116)}$ 'facing a certain number of scenarios for action; scenarios that may be modified according to the information that will come during the course of action and following the unexpected that will emerge and disturb the action'.

For keeping consistency between theory and method, it is necessary to search techniques and procedures that enable this 'thinking activity of the subject' guided and supported by theoretical support. The minimum maps of institutional social network can help the research and researchers with meeting this demand. Following, will be presented the experience of using such maps as a multidimensional methodological strategy.

\section{RESULTS - OUR EXPERIENCE}

In the development of a doctoral thesis in Health Sciences aimed at understanding the network of care for families involved in domestic violence against children and adolescents (VDCCA - violência doméstica contra crianças e adolescentes) from the perspective of professionals from health centers (CS - centros de saúde) of a municipality in the countryside of the state of São Paulo ${ }^{(16)}$, under the view of complex thinking, it was possible to use the Minimum Map of the Personal Social Network created by the Argentinian psychiatrist Sluzki ${ }^{(17)}$ and adapted by $\mathrm{Ude}^{(18)}$ for institutional contexts. The minimum map of the External Institutional Social Network aims to identify institutional bonds and gaps for the interventional work of the surveyed institutions. In the study, built data were complemented by focus groups and semi-structured interviews. Study participants were 41 health professionals from five participating units. The study was approved by the Research Ethics Committee of the Ribeirão Preto School of Nursing of the Universidade de São Paulo under protocol number CAAE 01726512.0.00005393, number 217/2012.

The minimum map of the External Institutional Social Network aims to identify institutional bonds and gaps for the interventional work of the surveyed institutions. The coordination of this map with the context of a given problem or node to be investigated allows the construction of an identity, representation and signaling of aspects that could compose a whole, with a global and articulated vision of the component parts in order to understand its context ${ }^{(19)}$. This coordination allows 'the discovery of context (...) the way to interconnect the warp and yarns in a fabric, find out what is woven together to understand its complexity'(19:42).

This map proposes to show the constitution of bonds between the institution evaluated and the organized groups in the community, as well as the various governmental and non-governmental organizations, in order to identify the existing resources and gaps, with view to integrate, strengthen, and optimize the existing community network. Thus, the map promotes the interconnection of the yarns, the perception of the weft, the evidence of significant relationships between the different aspects and possibilities to approach a theme, at the same time that it integrates, distinguishes and differentiates them from a broad view of the context.

The first movement of the map drawing is characterized by the construction of indicators regarding the bonds of the evaluated institution in relation to the other institutions in the fields of education, health, legal, security, religion, environment, work, leisure, culture, welfare, families, and the governing body. In this sense, the name of the studied institution is placed in the center of the map, and the close, intermediate and distant bonds are located in the different fields mentioned. To indicate the various institutions, programs and groups identified were used abbreviations such as: $\mathrm{CP}$ - Child Protection Agency; EC - Evangelical Church; CC - Catholic Church; BF - Bolsa Família (social welfare program). The quality of the bonds is indicated by lines to refer to the significant, fragile, broken or non-existent bonds.

A second movement can occur, which becomes evident by trying to verify how the bonds between institutions and groups are mapped in the different quadrants. Simultaneously, the inter-relationships established between these bodies and the others indicated on the map are evaluated. Remember that the lines must be qualified following the aforementioned parameter, i.e., the significant, fragile, broken or non-existent bonds.

When this part is finished, begins the design evaluation according to the following criteria: size; density; distribution and composition; dispersal; homo or heterogeneity. In this study, the green, yellow and red colors were used to represent, respectively, the significant, fragile and non-existent or broken bonds. Considering the diversity and multidimensionality of the surveyed universe, the lines characterizing the minimum map were dashed, indicating the permeability between the dimensions and the circularity and non-linearity of information. The units in this sector were inserted into the external network due to the complex organization of health systems. Moreover, there were no discussions about the inter-relationships between the institutions mapped in the areas given the depth of knowledge required for that.

The health centers participating in the study were designated by numbers $1,2,3,4$ and 5 , following the order in which data collection was carried out to keep confidentiality. 
The following script was used to prepare the maps: presentation of the purpose of the activity; introductory activity, with presentation of the activity participants; explanation of the paradigm of networks and the importance of bonds between sectors and institutions; explanation about completing the minimum map, which constitutes a diagnosis, allowing the visualization of the institution in the care network to families involved in VDCCA; preparation of maps, requiring a large paper with the map basic outline; colored pencils in black, green, yellow and red colors; adhesive tape. For the elaboration, with the group sitting in a semicircle, participants were asked to observe the quadrants representing the various sectors in the diagram provided, with the possibility of adding or replacing institutions, by specifying the services with which the institution relates. The institutions were placed closer and more distant according to the geographical distance from the institution occupying the center of the map. Later, observing the legend, lines were drawn to indicate the quality of bonds between each institution. Lines are drawn from one institution to another, characterizing the network of services and their relationships. Later, there was a discussion about the bonds between the health centers and the other institutions.

The diagrams were previously prepared and printed on $90 \times 110 \mathrm{~cm}$ sheets for better visualization. As the participants were members of a particular team, they had difficulty with talking about the other teams of the unit. Despite this issue, they brought dense and extensive discussion about the bonds with other units of the health sector and other sectors. The map elaborated in a studied health center is presented below:

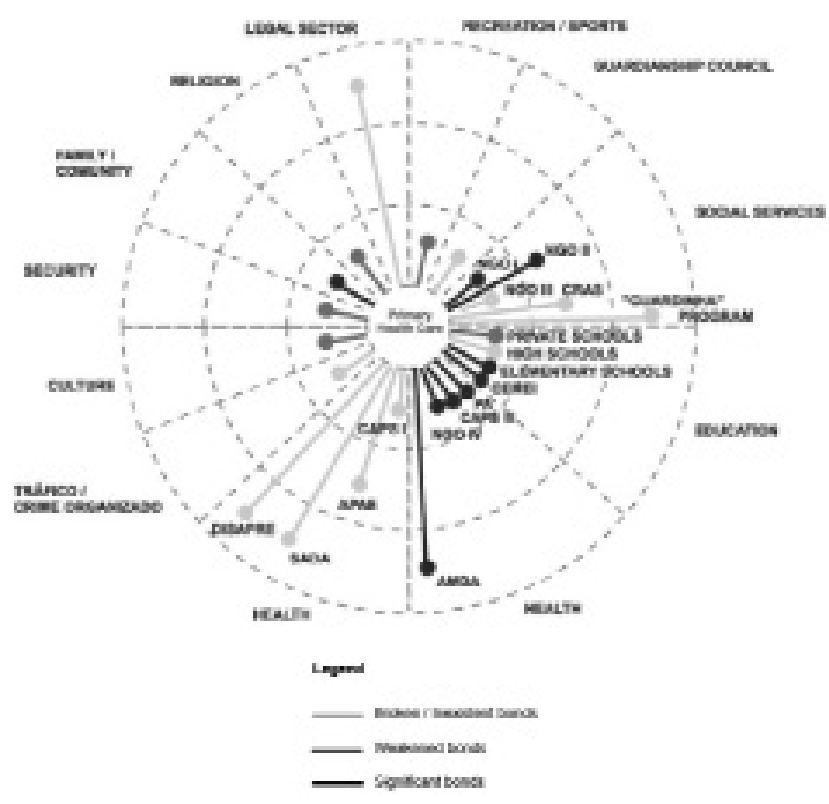

Figure 1 - Minimum Map of the External Institutional Social Network of the health center 1. Campinas, 2014.

After the map elaboration, it is interesting to use other instruments to complement and enable greater depth in the discussion (UDE, 2008). Hence, we complemented the data collection through focus groups, using the maps ela- borated by professionals to trigger discussions; and semi-structured interviews to clarify some specific points, in particular the actions taken by health centers to act with families involved in VDCCA.

\section{DISCUSSION}

The use of minimum maps of the External Institutional Social Network provided important advances in the know-how of qualitative research in Health and Nursing as the aspects discussed below.

In a qualitative research, this approach is interesting because it allows adjustments of the object and type of research, the studied universe and population. This strategy is important to trigger discussions in research because it allows a better understanding of the context and facilitates the reflective process of research participants. Still in this sphere, the strategy allows a 'view from within' the services, leading to discussion and problematization of the processes of work and management of care to the population.

In this sense, the strategy is not only important in research, but for promoting reflection spaces among health professionals, particularly in nursing, on knowledge and know-how. However, changing the praxis of professionals does not occur through programs of action and plans, but depends on the worldview, which is a slow and procedural movement initiated during training and maintained throughout the professional career ${ }^{(13)}$. Thus, it can be the object of continuing education for professionals, because this is a joint construction without pre-established concepts or conceptions, enabling a multidimensional view of reality and acting as a facilitator instrument of interventions.

The literature in the area corroborates the relevance of using multidimensional research methodologies ${ }^{(7,20)}$, because these are important strategies for action research, with the discussion and construction of intervention projects that are more efficient and based on the services practice ${ }^{(21)}$. In this context, active and multidimensional methodologies should not be used as mere tools aimed at vocational training or educational activities in the service. The subjects must participate actively in the teaching-learning process, seek knowledge and take ownership of knowledge to reach efficiency. They should also critically reflect on what was aprehended and then take actions and transform the reality in which they live ${ }^{(22)}$.

Beyond the scope of the study, but still in line with the complex paradigm, in which research and practice are not separated nor fragmented (also another challenge to overcome), the map contributes significantly to this dialogue and the dialogue between theory and practice. First, it is linked to the current guidelines of the World Health Organization, specifically with respect to organization of care to populations in network, with interdisciplinary and inter-sector coordination $^{(23,24,25)}$. In practice, it requires overcoming the restricted and independent view of each discipline, profession, service, and healthcare sector about the problem in order to enable the establishment of a common care project where each professional and every care sector has its share of specific contribution but interdependently ${ }^{(26)}$. 
In this sense, the map favors the action in networks, which has emerged as a new process in opposition to the traditional approaches of public policies that are guided in fragmented, punctual and compensatory actions, creating simplified and targeted interventions before complex phenomena ${ }^{(18)}$. It starts from the assumption of institutional incompleteness, in which no institution can solve all the problems isolatedly from its environment ${ }^{(18)}$. This conception presents a systemic, dialectical and complex character ${ }^{(10-17)}$. Furthermore, it provides a graphic visualization of relationships and bonds, facilitating the necessary diagnosis and problematization, and acting as an important strategy of planning and management of health services.

\section{CONCLUSION}

The moment of paradigm shift in science and health is at the same time, a challenging moment that demands the search and development of new strategies to expand the understanding of reality toward the polydimensiona- lity, the inter- and transdisciplinarity and multiplicity of knowledge involved in professional practice.

By recognizing the map as an important strategy in the context of qualitative research, the attention turns to practices contextualized and rooted in local cultures, also recognizing the need for a critical (re)reading of the theories and methods that base the professional practice.

The map allows the broad contextualization of the study object, favoring the understanding of the multiple dimensions involved in the nursing actions in the current line of care. By identifying the multiple dimensions of context, the map allows the identification of possibilities for implementing multi and interdisciplinary actions, and inter-sectoral in line with the current guidelines of policies in the health area.

From this perspective, the use of minimum maps of Institutional Social Network can be encouraged and strengthened to meet the current demands of the contemporary world, particularly for its flexibility in adapting to various research objects; broadness and depth of discussion; and possibilities of articulation with the services practice.

\section{RESUMO}

Objetivo: analisar o uso de estratégias metodológicas em pesquisas qualitativas - Mapa mínimo da Rede Social Institucional, como proposta para compreender os fenômenos na perspectiva multidimensional. Método: ensaio teórico metodológico em que buscou-se refletir sobre o uso de estratégias metodológicas inovadoras de pesquisa na enfermagem, sustentada nos fundamentos do Pensamento Complexo. Resultados: O mapa mínimo da Rede Social Institucional Externa tem o objetivo de identificar os vínculos institucionais e lacunas para o trabalho de intervenção das instituições pesquisadas. O uso destes mapas proporcionou avanços importantes no saber-fazer pesquisa qualitativa em Saúde e Enfermagem. Conclusão: Nessa perspectiva, o uso de mapas mínimos da Rede Social Institucional pode ser estimulado e potencializado para responder às atuais demandas da contemporaneidade, em especial pela sua flexibilidade na adequação a diversos objetos de pesquisa; amplitude e profundidade de discussão; e possibilidades de articulação com a prática dos serviços.

\section{DESCRITORES}

Pesquisa Qualitativa; Enfermagem; Rede comunitária.

\section{RESUMEN}

Objetivo: Analizar el uso de estrategias metodológicas en la investigación cualitativa - Mapa mínimo de la Intitucional de la Red Social, tal como se propone para comprender los fenómenos en la perspectiva multidimensional. Método: ensayo teórico metodológico en el que hemos tratado de reflexionar sobre el uso de estrategias metodológicas innovadoras en la investigación en enfermería, apoyados en los fundamentos del Pensamiento Complejo. Resultados: El mapa mínimo de Red Externa Institucional Social tiene como objetivo identificar los vínculos institucionales y carencias para el trabajo de intervención de las instituciones encuestadas. El uso de estos mapas proporcionan importantes avances en los conocimientos técnicos de investigación cualitativa en salud y enfermería. Conclusión: En esta perspectiva, el uso de mapas mínimos Institucional de red social puede ser estimulada y mejorada para satisfacer las demandas actuales del mundo contemporáneo, sobre todo por su flexibilidad para adaptarse a diferentes sujetos de la investigación; amplitud y profundidad de la discusión; y posibilidades con servicios de la salud.

\section{DESCRIPTORES}

Investigación Cualitativa; Enfermería; Red Social.

\section{REFERENCES}

1. Starfield B, Shi L, Macinko J. Contribution of primary care to health systems and health. Milbank Q. 2005;83(3):457-502.

2. Buss PM. Promoção da saúde e qualidade de vida. Ciênc. Saúde Coletiva. 2000;5(1):163-77. DOI: 10.1590/S1413-81232000000100014

3. Brasil. Ministério da Saúde; Secretaria de Vigilância em Saúde. Política nacional de promoção da saúde. Brasília; 2006.

4. Brasil. Ministério da Saúde; Secretaria de Atenção à Saúde.Política Nacional de Humanização da Atenção e Gestão do SUS. Redes de Produção da Saúde. Brasília;2009.

5. Feriotti ML. Construção de Identidade(s) na T. Ocupacional no Contexto das Transformações Paradigmáticas daSaúde e da Ciência. In: Terapia Ocupacional e Complexidade Práticas Multidimensionais. Curitiba: Editora CRV; 2013.

6. Brasil. Ministério da Saúde, Secretaria de Atenção à Saúde. Departamento de Atenção Básica. Política Nacional de Atenção Básica. Brasília; 2012.

7. Santos SSC, Hammerschmidt KSA. A complexidade e a religação de saberes interdisciplinares: contribuição do pensamento de Edgar Morin. Rev Bras Enferm. 2012; 65(4): 561-5. DOI: 10.1590/S0034-71672012000400002 
8. Campos CMS, Silva BRB, Forlin DC, Trapé CA, Lopes IO. Emancipatory practices of nurses in primary health care: the home visit as an instrument of health needs assessment. Rev. esc. enferm. USP. 2014;48(spe):119-25. DOI: 10.1590/S0080-623420140000600017

9. Gomes NP, Erdmann AL. Conjugal violence in the perspective of "Family Health Strategy" professionals: a public health problem and the need to provide care for the women. Rev. Latino-Am. Enfermagem. 2014;22(1):76-84. DOI: 10.1590/0104-1169.3062.2397.

10. Morin E. Ciência com consciência. 8 ed. Rio de Janeiro: Bertrand Brasil; 2005.

11. Morin E, Le Moigne, J. A Inteligência da Complexidade. São Paulo: Editora Petrópolis; 2000.

12. Morin, E. Os Sete Saberes Necessários à Educação do Futuro. 2a . ed. Brasília; 2000.

13. Alhadeff-Jones M. Revisiting Educational Research Through Morin's Paradigm of Complexity. Complicity: An International Journal of Complexity and Education. 2009;6(1):61-70.

14. Morin, E. O Método, Volume 3, O Conhecimento do Conhecimento. Porto Alegre: Ed. Sulina; 1999.

15. Morin, E. Introdução ao Pensamento Complexo. 5a . ed. Lisboa: Instituto Piaget; 2008.

16. Carlos DM. O cuidado em rede a famílias envolvidas na violência contra crianças e adolescentes: o olhar da Atenção Básica à Saúde [master's thesis]. [Ribeirão Preto (SP)]: Escola de Enfermagem de Ribeirão Preto da Universidade de São Paulo; 2014. 212p.

17. Sluzki CE. A rede social na prática sistêmica: alternativas terapêuticas. São Paulo: Casa do Psicólogo; 1997.

18. Ude W. Enfrentamento da violência sexual infantojuvenil e construção de redes sociais: produção de indicadores e possibilidades de intervenção. In: Cunha EP, Silva EM, Giovanetti MAC. Enfrentamento à violência sexual infantojuvenil: expansão do PAIR em Minas Gerais. Belo Horizonte: UFMG; 2008. p.30-60.

19. Pádua EMM. Pesquisa e Complexidade: Estratégias Metodológicas Multidimensionais. Curitiba: Ed. CRV; 2014.

20. Vieira LB, Souza IEO, Tocantins FR, Pina-Roche F. Support to women who denounce experiences of violence based on her social network. Rev. Latino-Am. Enfermagem. 2015; 23(5):865-73. DOI: 10.1590/0104-1169.0457.2625.

21. Vasconcelos EM. Complexidade e Pesquisa Interdisciplinar. $4^{a}$.ed. Rio de Janeiro: Ed. Vozes; 2009.

22. Diaz-Bordenave J, Pereira AM. Estratégias de ensino-aprendizagem. $28^{\mathrm{a}}$ ed. Petrópolis: Vozes; 2007.

23. Clarke A, Wydall S. From 'Rights to Action': practitioners' perceptions of the needs of children experiencing domestic violence. Child and Family Social Work. 2015;20:181-90.

24. Turner W, Broad J, Drinkwater J, Firth A, Hester M, Stanley N, Szilassy E, Feder G (in press). Interventions to improve the response of professionals to children exposed to domestic violence and abuse: a systematic review. Child Abuse Review. DOI: 10.1002/ car.2385.

25. Sylaska KM, Edwards KM. Disclosure of intimate partner violence to informal social support network members: a review of the literature. Trauma, Violence \& Abuse. 2014;15:3-21.

26. Schraiber LB, D'Oliveira AF, Hanada H, Kiss L. Assistência a mulheres em situação de violência - da trama de serviços à rede intersetorial. Athenea Digital. 2012;12(3):1-24. DOI: 10.5565/rev/athenead/v12n3.1110 